\title{
Metal Transport Parameters in Residual Soil with an Undisturbed and Remolded Structure Percolated by an Acid Solution
}

\author{
Eduardo Pavan Korf ${ }^{1}$, Antonio Thomé ${ }^{2}$, Nilo Cesar Consoli ${ }^{1}$, Rafael de Souza Tímbola ${ }^{2}$, \\ Gláucia Carine dos Santos ${ }^{1}$ \\ ${ }^{1}$ Department of Civil Engineering, Federal University of Rio Grande do Sul, Porto Alegre, Brazil; ${ }^{2}$ University of Passo Fundo, Passo \\ Fundo, Brazil. \\ Email: eduardokorf@gmail.com
}

Received July $18^{\text {th }}, 2011$; revised August $21^{\text {st }}, 2011$; accepted September $22^{\text {nd }}, 2011$.

\begin{abstract}
There is no enough information about metal transport parameters in residual soil. These soils are generally structured and still there is no answer to what happens with the contaminant transport parameters when an acid solution with metal percolates this material with different structure. The objective of this study was to determine the contaminant transport parameters for $\mathrm{Cd}, \mathrm{Ni}, \mathrm{Cu}$ and $\mathrm{Zn}$ metals in an acid multispecies solution to a residual soil from south Brazil with an undisturbed and remolded structure. Column tests were carried out to determine the $R_{d}, k_{d}, D_{h}$ transport parameters. It was possible conclude that the magnitude of the $k_{d}, R_{d}$ and $D_{h}$ parameter did not vary significantly with the soil structure.
\end{abstract}

Keywords: Pollutant Transport, Column Equipment, Natural Attenuation, Dissolved Metals, Analytical Simulation

\section{Introduction}

Acidic and inorganic materials in residual water represent a common effluent from industrial activities such as mining (coal and mineral deposits), electroplating, casting and the handling of chemical substances in general. These effluents, if not well managed, may generate environmental pollution and have a negative impact on soil, superficial and underground water and ecosystems [1$11]$.

The metals when inserted in the environment may cause serious damage to toxicity in exposed organisms, because metals may be inserted in the food chain due to their high mobility. [12] have claimed that contamination by metals may lead to both acute and chronic high toxicity, persist in an environment, high mobility and accumulate in organisms due to their liposolubility. Additionally, metal compounds, even in small amounts, may be toxic to plants and animals $[13,14]$.

Studies are needed to provide an understanding of the control mechanisms of solution with metallic compounds on the residual soil, mainly from south Brazil. Such studies should be conducted with the objective of monitoring the contamination plumes migration and carried out environmental models studies. Additional studies might also accelerate immobilization and decontamination projects or suspend such procedures for verifying effectiveness of natural attenuation processes [15].

The migration of pollutants to the subsurface is influenced by several factors that may determine the movement of metal through the soil. These factors are described by physical and biophysical-chemical processes, which are represented by the theoretical model. The physical process, in general, involves diffusion and mechanical dispersion phenomena, and one may be predominant over the other. The summation of those two processes is called hydrodynamic dispersion $\left(\mathrm{D}_{\mathrm{h}}\right)$. This phenomenon is characterized in the diffusive part by molecular diffusion coefficient $\left(D^{*}\right)$, which is represented by the direct relationship between the coefficient diffusion in free solution $\left(\mathrm{D}_{\mathrm{o}}\right)$ and a physical-chemical factor called tortuosity $(\tau)$. In the dispersive part of transport, the phenomena are represented by the mechanical dispersion $(\alpha)$ and the percolation speed $\left(\mathrm{v}_{\mathrm{s}}\right)$. The biophysicochemical processes are related to the physical, chemical and biological interactions that may occur between the soil and the pollutant. In those processes, the interaction between the environmental conditions, the 
pollutant and the porous media may cause the delay, acceleration or degradation of pollution. The parameter that governs these processes is the retardation factor $\left(\mathrm{R}_{\mathrm{d}}\right)$ which is directly co-related with the distribution coefficient $\left(\mathrm{k}_{\mathrm{d}}\right)$. All the contaminant transport parameters can be determined through laboratory experiments such as column tests, diffusion tests and batch tests. Also, they can be estimated according to literature data and by correlations or through retro-analysis with analytical or numeric solutions [16-27,5,7]).

The objective of this study was to determine the contaminant transport parameters of for $\mathrm{Cd}, \mathrm{Ni}, \mathrm{Cu}$ and $\mathrm{Zn}$ metals dissolved in a $\mathrm{pH}$ multispecies acid solution in a residual soil with undisturbed and remolded structures. Both soil structures were evaluated with the objective of simulating, respectively, the condition of a natural barrier in the field as well as a remolded condition that represents the artificial soil barrier to prevent the percolation of an acidic and inorganic pollutant.

\section{Experimental Program}

\subsection{Materials}

\subsubsection{Residual Soil}

The soil utilized in the present research was a basaltic residual soil sampled from the Geotechnical Experimental Site of the University of Passo Fundo, located in southern Brazil.

According to [28] the pedological classification is a Humic Oxisol. These soils are very deep, drained and highly weathered, and they show a sequence of A-Bw-C horizons, where $\mathrm{Bw}$ is a oxisol type. In this study was used the $\mathrm{Bw}$ horizon only. These soils have very little clay increase with depth, and there is a gradual transition between the horizons. Because the soils were very weathered, there is a dominance of kaolinite and iron oxides, which gave the soil samples a low CEC (cation exchange capacity), strong acidity and a low stock of nutrients. Its red color indicates that the soil had a low base saturation and high iron content [29].

Regarding of chemical characterization, the residual soil used has an acidic $\mathrm{pH}$ (5.4), high clay content (68\%), low organic matter content $(<0.8 \%)$ and low CEC $(8.6$ cmolc $/ \mathrm{dm}^{3}$ ), which is typical of soils with the predominance of kaolinite clay mineral. The geotechnical characterization, based on characterization tests, indicated soil is clay and have high compressibility - $\mathrm{CH}$ [29].

The mineral characterization, related to the specific superficial area (SSA-was $33.86 \mathrm{~m}^{2} \cdot \mathrm{g}^{-1}$ ), indicated a predominance of kaolinite clay, according to the range of values proposed by [30,31].

\subsubsection{Pollutant Solution}

The pollutant solution contained metals dissolved in dis- tilled water with $\mathrm{pH} 1.35$. This value was used to reproduce the condition of high solubility, attempting to avoid precipitation chemical reactions. The metals concentration in the pollutant solution used in column tests were defined according to increasing the intervention value for underground water from Company of Technology in Environmental Sanitation-CETESB [32]. The intervention value indicates the need of remediation actions for the possible risks receptors [32].The increase this value represents an extreme condition of contamination, requiring monitoring or remediation measures. These values as well as the inserted concentration to different metal used in this study are presents in Table 1.

\subsection{Methods}

\subsubsection{Molding of the Test Samples}

Each sample was taken from the field in its undisturbed form from the B horizon of the soil (1.2 $\mathrm{m}$ depth). In the laboratory, the cylindrical test samples (TS) were molded with an undisturbed and remolded structure. The remolded test samples had approximately the same density and natural moisture as the undisturbed samples. The diameter of the test samples was $5 \mathrm{~cm}$ and the heights of the samples were variable. Tables $\mathbf{2}$ and $\mathbf{3}$ show the physical properties for the test samples with undisturbed and remolded structures, respectively.

\subsubsection{Column Test}

The column test reproduces the transport of a pollutant through the soil and is used for determination of physical

Table 1. Concentration of metals inserted in the columns tests.

\begin{tabular}{cccc}
\hline Metal & $\begin{array}{c}\text { CETESB } \\
\text { Intervention } \\
\left(\mathrm{mg} \cdot \mathrm{L}^{-1}\right)\end{array}$ & Increasing & $\begin{array}{c}\text { Inserted } \\
\text { Concentration } \\
\left(\mathrm{mg} \cdot \mathrm{L}^{-1}\right)\end{array}$ \\
\hline $\mathrm{Ni}$ & $<0.02$ & 100 & 2 \\
$\mathrm{Cr}$ & $<0.05$ & 100 & 5 \\
$\mathrm{~Pb}$ & $<0.01$ & 100 & 1 \\
$\mathrm{Cd}$ & $<0.005$ & 100 & 0.5 \\
$\mathrm{Zn}$ & $<5$ & 2 & 10 \\
$\mathrm{Cu}$ & $<2$ & 2.5 & 5 \\
$\mathrm{Mn}$ & $<0.4$ & 2 & 0.8 \\
\hline
\end{tabular}

Table 2. Physical properties of the test samples with an undisturbed structure.

\begin{tabular}{cccccccc}
\hline $\begin{array}{c}\text { Test } \\
\text { sample }\end{array}$ & $\begin{array}{c}\text { Moisture } \\
\text { content } \\
(\%)^{*}\end{array}$ & $\begin{array}{c}\text { Height } \\
(\mathrm{cm})\end{array}$ & $\begin{array}{c}\text { Diameter } \\
(\mathrm{cm})\end{array}$ & $\begin{array}{c}\text { Specific. } \\
\text { mass } \\
\left(\mathrm{g} \cdot \mathrm{cm}^{-3}\right)^{*}\end{array}$ & $\begin{array}{c}\text { Void } \\
\text { ratio }\end{array}$ & $\begin{array}{c}\text { Void } \\
\text { Porosity volume } \\
\left(\mathrm{cm}^{3}\right)\end{array}$ \\
\hline 1 & 35.27 & 9.22 & 4.93 & 1.50 & 1.41 & 0.59 & 102.74 \\
2 & 32.50 & 6.40 & 5.17 & 1.43 & 1.46 & 0.59 & 79.85 \\
3 & 34.62 & 8.66 & 4.57 & 1.51 & 1.38 & 0.58 & 82.38 \\
\hline
\end{tabular}

*Moisture and density equivalent to molding field. 
Table 3. Physical properties of test samples with a remolded structure.

\begin{tabular}{ccccccccc}
\hline $\begin{array}{c}\text { Test } \\
\text { sample }\end{array}$ & $\begin{array}{c}\text { Moisture } \\
\text { content } \\
(\%)^{*}\end{array}$ & $\begin{array}{c}\text { Height Diameter } \\
(\mathrm{cm})\end{array}$ & $\begin{array}{c}\text { Specific. } \\
(\mathrm{cm})\end{array}$ & $\begin{array}{c}\text { mass } \\
\left(\mathrm{g} \cdot \mathrm{cm}^{-3}\right)^{*}\end{array}$ & $\begin{array}{c}\text { Void } \\
\text { ratio }\end{array}$ & $\begin{array}{c}\text { Porosity } \\
\text { volume } \\
\left(\mathrm{cm}^{3}\right)\end{array}$ \\
\hline 4 & & 11.44 & 5 & 1.58 & 1.27 & 0.56 & 125.67 \\
5 & 34.62 & 9.64 & 5 & 1.56 & 1.29 & 0.56 & 106.70 \\
6 & & 7.96 & 5 & 1.55 & 1.38 & 0.57 & 88.82 \\
\hline
\end{tabular}

*Moisture and density equivalent to molding field.

and physical-chemical transport parameters. The test was conducted with equipment produced according to the [29]. The test consisted of two steps; the first stage the distilled water was percolated until flow steady state, where the hydraulic conductivity was determined. In the second stage was percolated the pollutant solution. For each soil structure, three test samples were tested simultaneously.

After percolating the pollutant solution through the soil, the liquid was collected in different percolated volume and tested times. The metal concentration in each collected samples was determined through analysis with an atomic absorption spectrophotometer.

After determining metal present in the percolated effluent from the test samples, it was possible to obtain the breakthrough curves for each test and metal pollutant. The breakthrough curve gives the number of percolated pores (percolated volume/void volume-Vperc/Vv) or the percolation time $(\mathrm{T})$ along the $\mathrm{x}$ axis, and the pollutant relative concentration (percolated effluent concentration/initial concentration- $\mathrm{C} / \mathrm{Co}$ ) is given along the $\mathrm{y}$ axis.

Tables 4 and 5 show the hydraulic characteristics of each test sample for the undisturbed and remolded structures, respectively.

\subsubsection{Determination of Transport Parameters}

Reference [33] developed a one-dimensional analytical solution (1D) for the flow in homogenous and saturated soils using both initial and boundary conditions: $\mathrm{C}(\mathrm{x}, 0)$ $=0$ for $\mathrm{x} \geq 0 ; \mathrm{C}(0, \mathrm{t})=\mathrm{C}_{\mathrm{o}}$ for $\mathrm{t} \geq 0 ; \partial \mathrm{C}(\infty, \mathrm{t}) / \partial(\mathrm{t})=0$ for $t \geq 0$. The Equation (1) shows the analytical solution for a reactive solute for the occurrence of delay biophysicalchemical processes. In the equation, $\mathrm{C} / \mathrm{Co}$ is the ratio between measured percolated effluent concentration and the initial concentration, erfc is a function of the supplementary error, $R_{d}$ is the delay factor, $L$ is the one-dimensional flow distance given by the height of the test sample, $v_{s}$ is the percolation speed, $t$ is the time of the test, and $\mathrm{Dh}$ is the hydrodynamic dispersion coefficient.

To determine the $D_{h}$ parameter, a theoretical curve was adjusted at experimental transport curve (break-
Table 4. Hydraulic characteristics of test samples with undisturbed structure.

\begin{tabular}{ccc}
\hline Test & $\mathrm{k}\left(\mathrm{cm} \cdot \mathrm{s}^{-1}\right)$ & $\mathrm{v}_{\mathrm{s}}\left(\mathrm{cm} \cdot \mathrm{s}^{-1}\right)$ \\
\hline 1 & $5.90 \times 10^{-04}$ & $7.66 \times 10^{-03}$ \\
2 & $3.70 \times 10^{-04}$ & $6.92 \times 10^{-03}$ \\
3 & $1.40 \times 10^{-04}$ & $3.24 \times 10^{-03}$ \\
\hline
\end{tabular}

Table 5. Hydraulic characteristics of test samples with remolded structure.

\begin{tabular}{ccc}
\hline Test & $\mathrm{k}\left(\mathrm{cm} \cdot \mathrm{s}^{-1}\right)$ & $\mathrm{v}_{\mathrm{s}}\left(\mathrm{cm} \cdot \mathrm{s}^{-1}\right)$ \\
\hline 4 & $8.07 \times 10^{-05}$ & $2.78 \times 10^{-03}$ \\
5 & $1.42 \times 10^{-04}$ & $2.92 \times 10^{-03}$ \\
6 & $2.76 \times 10^{-04}$ & $6.77 \times 10^{-03}$ \\
\hline
\end{tabular}

through) from column test by the Ogata and Banks solution Equation (1). To generate a theoretical curve, the $\mathrm{C} / \mathrm{Co}$ values were found by establishing different time ranges ( $t$ ), the height of the test sample (or the flow distance along $\mathrm{x}(\mathrm{L}))$, the percolation speed $\left(\mathrm{v}_{\mathrm{s}}\right)$ and the parameters $R_{d}$. The $R_{d}$ parameter was obtained from a method given by [18], which defines the area above the transport curve as a value corresponding to $\mathrm{R}_{\mathrm{d}}$.

$$
\begin{aligned}
& \frac{C(x, t)}{C_{0}} \\
& =\frac{1}{2}\left[\operatorname{erfc}\left(\frac{R_{d} L-v_{s} t}{2 \sqrt{D_{h} R_{d} t}}\right)+\exp \left(\frac{v_{s} L}{D_{h}}\right) \operatorname{erfc}\left(\frac{R_{d} L+v_{s} t}{2 \sqrt{D_{h} R_{d} t}}\right)\right]^{(1)}
\end{aligned}
$$

The $k_{d}$ coefficient was obtained using a linear relationship between the mass absorbed by a unit of solid mass and the concentration of the substance in the solution when the soil is saturated, which was determined after equilibrium was reached. The parameter $k_{d}$ was determined according to Equation (2), where: $\mathrm{Rd}$ is the delay factor, $\rho_{\mathrm{s}}$ is the specific soil dry mass, and $\mathrm{n}$ is the porosity of the test sample [23].

$$
\mathrm{k}_{\mathrm{d}}=\frac{\mathrm{R}_{\mathrm{d}}-1}{\rho_{\mathrm{s}}} \times \mathrm{n}
$$

\section{Results}

\subsection{Column Tests}

Figures 1 to 4 show some results of columns tests with the adjustments performed for the analysis of the transport parameters for the residual soil. Only was showed the best adjustments results for each soil structure and tested metal. However, these results are representative of all tests, once the results were similar for each treatment. 


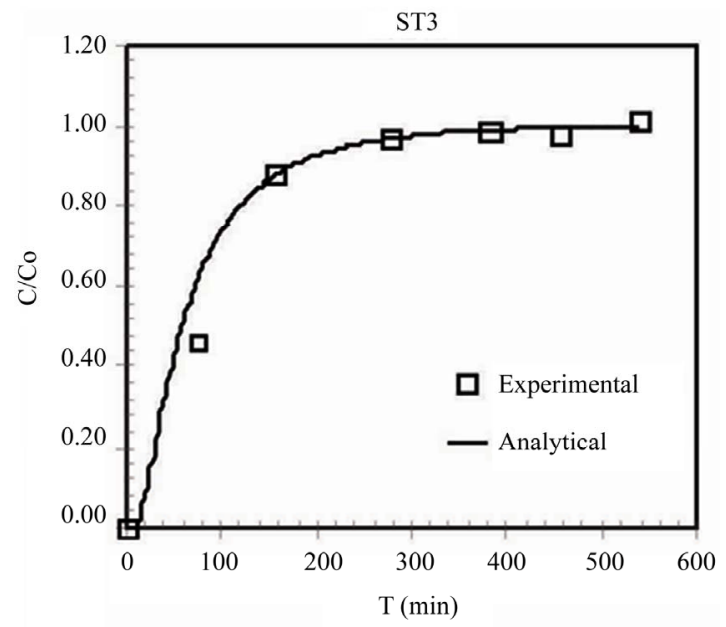

(a)

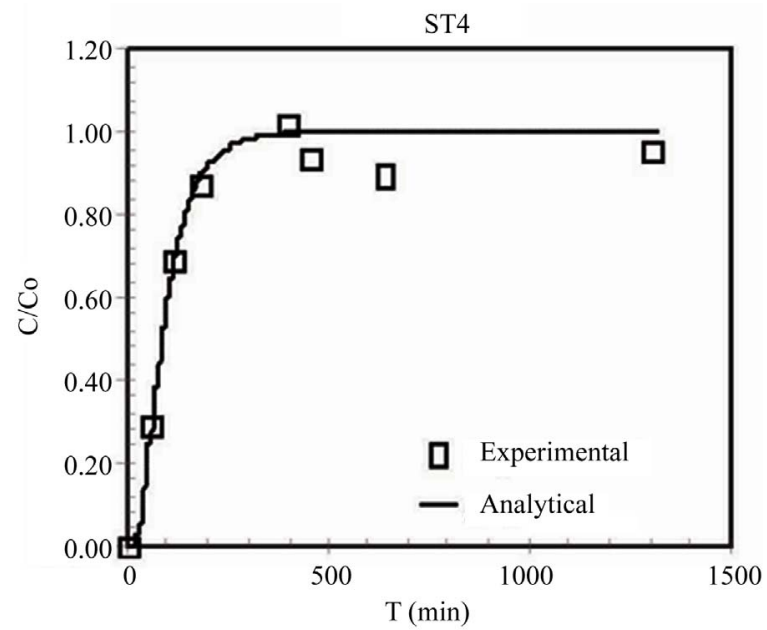

(b)

Figure 1. Column test results and adjustment analysis for cadmium metal (a) undisturbed; (b) remolded structure.

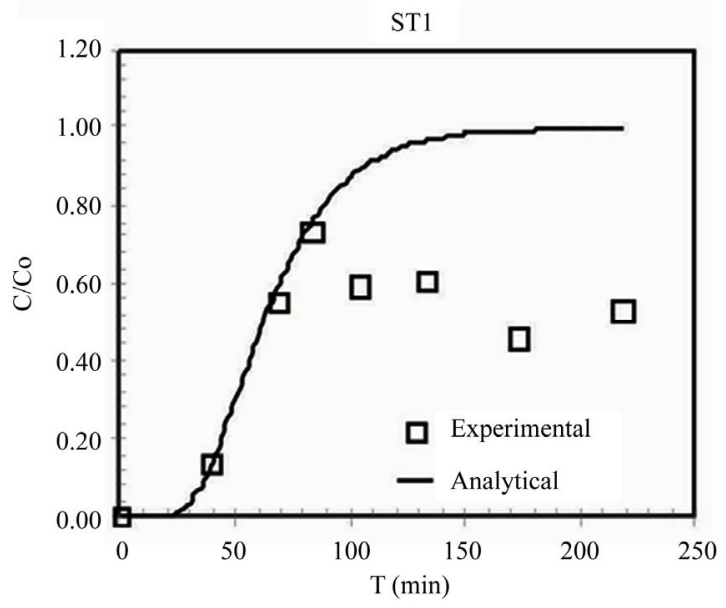

(a)

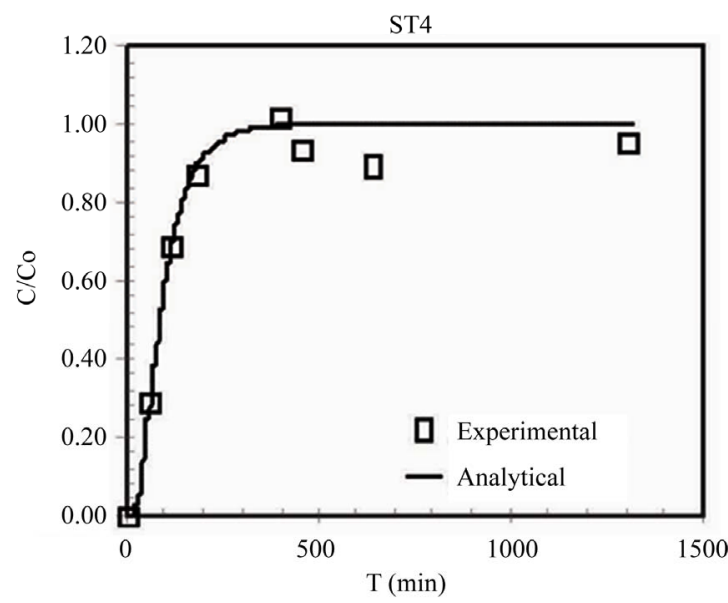

(b)

Figure 2. Column test results and adjustment analysis for nickel metal (a) undisturbed; (b) remolded structure.

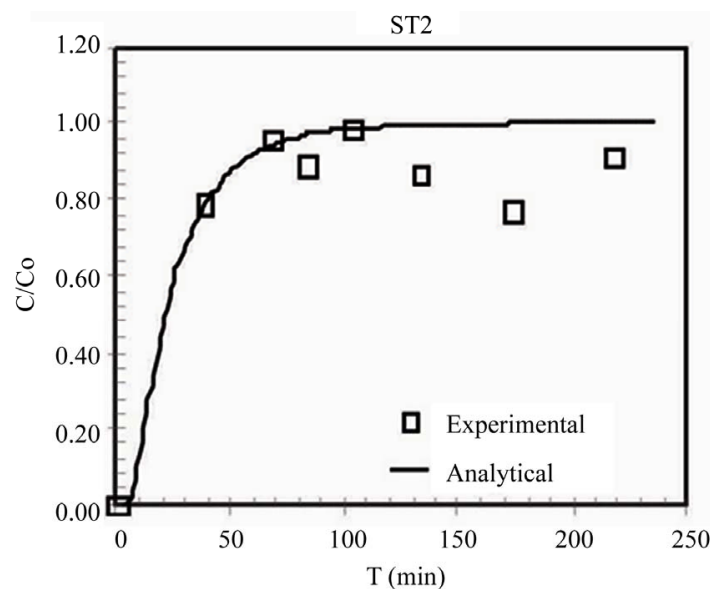

(a)

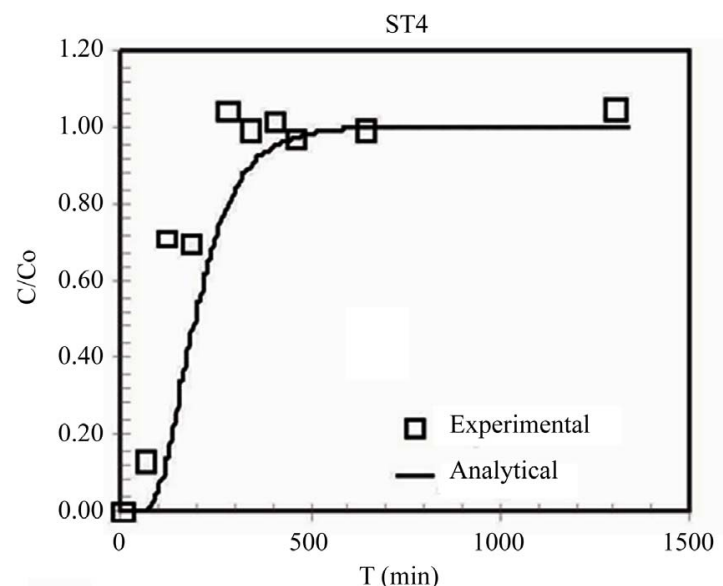

(b)

Figure 3. Column test results and adjustment analysis for zinc metal (a) undisturbed; (b) remolded structure. 


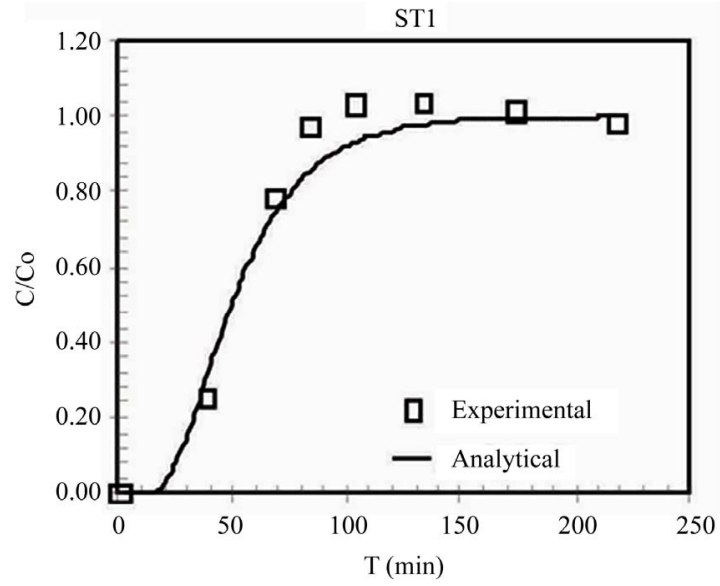

(a)

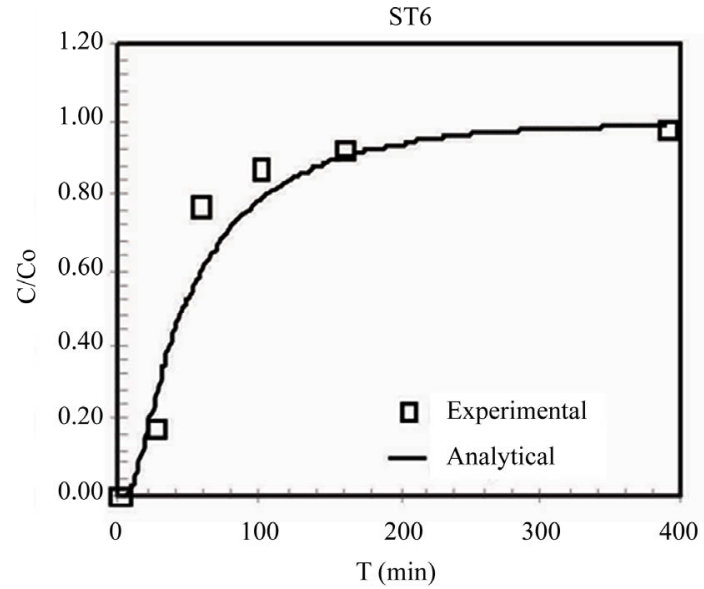

(b)

Figure 4. Column test results and adjustment analysis for copper metal (a) undisturbed; (b) remolded structure.

\subsection{Contaminant Transport Parameters}

Tables 6-9 show the contaminant transport parameters obtained for the tested metals with undisturbed and remolded structures at a $\mathrm{pH}$ of 1.35. Variance Analysis for treatments for $K_{d}, R_{d}$ and $D_{h}$ showed no significant difference between the structures to the metals: $\mathrm{Cd}, \mathrm{Ni}, \mathrm{Cu}$ and $\mathrm{Zn}$. Although the Ni metal have presented $\mathrm{p}=0.049$, this value is very close to 0.05 , which does not reveal significant differences with confidence $(\alpha=0.05)$. The tables also show the average value, standard deviation and coefficient of variation for the values of $k_{d}$ and $R_{d}$ and $\mathrm{D}_{\mathrm{h}}$ of each metal.

\section{Discussion}

Concerning the magnitude of parameters $\mathrm{k}_{\mathrm{d}}$ and $\mathrm{R}_{\mathrm{d}}$ there are no significant influence of the change of structure for the metals $\mathrm{Cd}, \mathrm{Ni}, \mathrm{Cu}, \mathrm{Zn}$. The similarity between the $\mathrm{k}_{\mathrm{d}}$ and $R_{d}$ values related to the structure don't agree with the finding of [34,35], who have reported that the disturbance of a remolded structure influences the pollutants mobility in soils. The authors have not related the $\mathrm{pH}$, but this may be true for higher values of $\mathrm{pH}$, which can decrease metals mobility in solution. In this study, the similar behavior found with different structures must be due to high mobility of metals in acidic $\mathrm{pH}$ (1.35), which possibly may have favored the transport in both structures.

Reference [36] simulated the concentration of a contaminating solution at $\mathrm{pH} 4.5$ and $5 \mathrm{mg} \cdot \mathrm{L}^{-1}$, which is close to most of the concentrations employed in the present study in soil with $90.6 \%$ kaolinite and $21 \%$ clay. They obtained $\mathrm{k}_{\mathrm{d}}$ values for $\mathrm{Cd}\left(4.9 \mathrm{~cm}^{3} \cdot \mathrm{g}^{-1}\right)$, Ni $(9.5$ $\left.\mathrm{cm}^{3} \cdot \mathrm{g}^{-1}\right), \mathrm{Cu}\left(15.0 \mathrm{~cm}^{3} \cdot \mathrm{g}^{-1}\right), \mathrm{Zn}\left(6.5 \mathrm{~cm}^{3} \cdot \mathrm{g}^{-1}\right)$. The values reported by [36] are similar to the ones found in the pre-
Table 6. Transport parameters obtained for cadmium metal.

\begin{tabular}{|c|c|c|c|c|}
\hline Structure & TS & $\mathrm{R}_{\mathrm{d}}$ & $\mathrm{k}_{\mathrm{d}}\left(\mathrm{cm}^{3} \cdot \mathrm{g}^{-1}\right)$ & $D_{h}\left(\mathrm{~cm}^{2} \cdot \mathrm{s}^{-1}\right)$ \\
\hline \multirow{3}{*}{ Undisturbed } & TS1 & 5.00 & 2.09 & $1.50 \times 10^{-2}$ \\
\hline & $\mathrm{TS} 2$ & 5.50 & 2.45 & $1.50 \times 10^{-2}$ \\
\hline & TS3 & 7.00 & 3.10 & $6.67 \times 10^{-3}$ \\
\hline \multirow{3}{*}{ Remolded } & TS4 & 3.64 & 1.26 & $1.17 \times 10^{-2}$ \\
\hline & TS5 & 6.52 & 2.66 & $8.33 \times 10^{-3}$ \\
\hline & TS6 & 5.00 & 1.98 & $1.67 \times 10^{-2}$ \\
\hline \multicolumn{2}{|c|}{$\mathrm{p}$} & 0.490 & 0.311 & 0.996 \\
\hline \multicolumn{2}{|c|}{ Average } & 5.44 & 2.26 & $1.22 \times 10^{-2}$ \\
\hline \multicolumn{2}{|c|}{ Standard Deviation } & 1.20 & 0.63 & $4.04 \times 10^{-3}$ \\
\hline \multicolumn{2}{|c|}{$\begin{array}{c}\text { Coefficient of variation } \\
(\%)\end{array}$} & 22.09 & 28.09 & 33.05 \\
\hline
\end{tabular}

*p value of variance analysis.

Table 7. Transport parameters obtained for nickel metal.

\begin{tabular}{|c|c|c|c|c|}
\hline Structure & TS & $\mathrm{R}_{\mathrm{d}}$ & $\mathrm{k}_{\mathrm{d}}\left(\mathrm{cm}^{3} \cdot \mathrm{g}^{-1}\right)$ & $D_{h}\left(\mathrm{~cm}^{2} \cdot \mathrm{s}^{-1}\right)$ \\
\hline \multirow{3}{*}{ Undisturbed } & TS1 & 6.70 & 2.98 & $6.67 \times 10^{-3}$ \\
\hline & $\mathrm{TS} 2$ & 9.00 & 4.36 & $1.00 \times 10^{-2}$ \\
\hline & TS3 & $* *$ & 7.23 & $1.17 \times 10^{-2}$ \\
\hline \multirow{3}{*}{ Remolded } & TS4 & 3.00 & 0.96 & $6.67 \times 10^{-3}$ \\
\hline & TS5 & 4.44 & 1.66 & $8.33 \times 10^{-3}$ \\
\hline & TS6 & 5.01 & 1.99 & $5.00 \times 10^{-2}$ \\
\hline \multicolumn{2}{|c|}{$\mathrm{p}$} & 0.049 & 0.046 & 0.520 \\
\hline \multicolumn{2}{|c|}{ Average } & 5.63 & 3.20 & $1.56 \times 10^{-2}$ \\
\hline \multicolumn{2}{|c|}{ Standard Deviation } & 2.30 & 2.30 & $1.70 \times 10^{-2}$ \\
\hline \multicolumn{2}{|c|}{ Coefficient of variation (\%) } & 40.91 & 72.00 & 109.14 \\
\hline
\end{tabular}

*The parameter could not be obtained. 
Table 8. Transport parameters obtained for copper metal.

\begin{tabular}{|c|c|c|c|c|}
\hline Structure & TS & $\mathrm{R}_{\mathrm{d}}$ & $\mathrm{k}_{\mathrm{d}}\left(\mathrm{cm}^{3} \cdot \mathrm{g}^{-1}\right)$ & $\mathrm{D}_{\mathrm{h}}\left(\mathrm{cm}^{2} \cdot \mathrm{s}^{-1}\right)$ \\
\hline \multirow{3}{*}{ Undisturbed } & $\mathrm{TS} 1$ & 5.50 & 2.35 & $1.00 \times 10^{-2}$ \\
\hline & TS2 & 7.97 & 3.80 & $3.33 \times 10^{-2}$ \\
\hline & $\mathrm{TS} 3$ & $* *$ & 6.20 & $6.67 \times 10^{-3}$ \\
\hline \multirow{3}{*}{ Remolded } & TS4 & 6.52 & 2.64 & $1.17 \times 10^{-2}$ \\
\hline & TS5 & 8.49 & 3.62 & $1.67 \times 10^{-3}$ \\
\hline & TS6 & 7.29 & 3.12 & $3.33 \times 10^{-2}$ \\
\hline \multicolumn{2}{|c|}{$\mathrm{p}$} & 0.590 & 0.940 & 0.710 \\
\hline \multicolumn{2}{|c|}{ Average } & 7.15 & 3.62 & $1.61 \times 10^{-2}$ \\
\hline \multicolumn{2}{|c|}{ Standard Deviation } & 1.18 & 1.38 & $1.38 \times 10^{-2}$ \\
\hline \multicolumn{2}{|c|}{ Coefficient of variation (\%) } & 16.55 & 38.08 & 85.37 \\
\hline
\end{tabular}

*The parameter could not be obtained.

Table 9. Transport parameters obtained for zinc metal.

\begin{tabular}{ccccc}
\hline Structure & TS & $\mathrm{R}_{\mathrm{d}}$ & $\mathrm{k}_{\mathrm{d}}\left(\mathrm{cm}^{3} \cdot \mathrm{g}^{-1}\right)$ & $\mathrm{D}_{\mathrm{h}}\left(\mathrm{cm}^{2} \cdot \mathrm{s}^{-1}\right)$ \\
\hline \multirow{4}{*}{ Undisturbed } & TS1 & 2.50 & 0.78 & $1.50 \times 10^{-2}$ \\
& $\mathrm{TS} 2$ & 3.50 & 1.36 & $1.50 \times 10^{-2}$ \\
& $\mathrm{TS} 3$ & 7.00 & 3.10 & $6.67 \times 10^{-3}$ \\
& $\mathrm{TS} 4$ & 3.11 & 1.01 & $3.33 \times 10^{-3}$ \\
Remolded & $\mathrm{TS} 5$ & 4.47 & 1.68 & $8.33 \times 10^{-3}$ \\
& $\mathrm{TS} 6$ & 4.29 & 1.63 & $4.17 \times 10^{-2}$ \\
& & 0.800 & 0.690 & 0.670 \\
Average & & 4.15 & 1.59 & $1.50 \times 10^{-2}$ \\
Standard Deviation & 1.58 & 0.82 & $1.39 \times 10^{-2}$ \\
Coefficient of variation $(\%)$ & 38.10 & 51.26 & 92.49 \\
\hline
\end{tabular}

sent study. [37] studied metals mobility in oxisol with $72 \%$ clay and kaolinite $70.9 \%$ and obtained Rd values of 1.34, 1.46 and 3.88 for $\mathrm{Zn}, \mathrm{Cd}$ and $\mathrm{Cu}$, respectively. These values are lower than the values obtained in this study. This is due the different structures and mineral formation for soil used.

With respect to the metal retention sequence, which was observed through the average parameters $\mathrm{k}_{\mathrm{d}}$ and $\mathrm{Rd}$, the following prevalence order was observed: $\mathrm{Cu}>\mathrm{Ni}>$ $\mathrm{Cd}>\mathrm{Zn}$. The affinity order obtained by [38], from residual oxisol in the state of São Paulo, Brazil, had a similar behavior for $\mathrm{Cu}$ and $\mathrm{Zn}$ metals. [5] claimed that $\mathrm{Cu}$ metal have reduced mobility in soil as compared to $\mathrm{Zn}, \mathrm{Ni}$ and $\mathrm{Cd}$ metals, which was confirmed by the results of this study. Relative to the kaolinite clay mineral, which was predominant in the studied soil, [19] found the following preference series for $\mathrm{pH}$ values of 3.5 to 6 : $\mathrm{Pb}>\mathrm{Ca}>\mathrm{Cu}>\mathrm{Mg}>\mathrm{Zn}>\mathrm{Cd}$. Similar results were obtained for the $\mathrm{Cu}$ and $\mathrm{Zn}$ metals in the current study. Vega et al. (2006) [36] obtained similar preference series, which only had opposite behavior between $\mathrm{Cd}$ and $\mathrm{Zn}$. [37] obtained equivalent preference series in the study of $\mathrm{Zn}, \mathrm{Cd}$ and $\mathrm{Cu}$ metals.

The results for parameter $\mathrm{D}_{\mathrm{h}}$, according to Tables 6-9, range from $10^{-3}$ to $10^{-2} \mathrm{~cm}^{2} \cdot \mathrm{s}^{-1}$ and, according to analysis of variance, no difference was found between the structures tested. [25] obtained $\mathrm{D}_{\mathrm{h}}$ values for $\mathrm{Cd}$ in the horizon $\mathrm{B}$ oxisol, resulting in an average value of $2.81 \times 10^{-4}$ $\mathrm{cm}^{2} \cdot \mathrm{s}^{-1} \cdot$ [20], obtained $D_{h}$ values for zinc in clayey soil used in compacted landfill barriers with average value of $1.78 \times 10^{-4} \mathrm{~cm}^{2} \cdot \mathrm{s}^{-1} \cdot$ [39], obtained $\mathrm{D}_{\mathrm{h}}$ values that ranged from $2.25 \times 10^{-5} \mathrm{~cm}^{2} \cdot \mathrm{s}^{-1}$ to $8.15 \times 10^{-5} \mathrm{~cm}^{2} \cdot \mathrm{s}^{-1}$ for a soil from a urban solid waste landfill, and they studied the presence of $\mathrm{Cd}, \mathrm{Cu}$ and $\mathrm{Zn}$ metals. The values obtained by those authors were lower than the values in the present study, which could be explained by the difference in structures and mineral formation and direct influence of the low $k_{d}$ and $R_{d}$ values, which also reduced the $D_{h}$ values, which have been obtained through these parameters.

\section{Conclusions}

In this work was studied the contaminant transport parameters to a clay residual soil from south Brazil with different structures (undisturbed and remolded) when percolated with an acid solution $(\mathrm{pH}=1.35)$. The following conclusions can be made:

- The $k_{d}, R_{d}$ and $D_{h}$ magnitude did not vary significantly with soil structure, thus, it is possible conclude that the soil structure did not influence the contaminant transport parameters for this residual soil;

- The metal retention sequence was $\mathrm{Cu}>\mathrm{Ni}>\mathrm{Cd}>$ Zn.

\section{REFERENCES}

[1] O. M. Bermea, E. H. Álvarez, I. Gaso and N. Segovia, "Heavy Metal Concentrations in Surface Soils from Mexico City," Bulletin of Environmental Contamination and Toxicology, Vol. 68, No. 3, 2002, pp. 383-388. doi:10.1007/s001280265

[2] E. P. Achterberg, C. B. Braungardt and G. E. Millward, "Metal Behaviour in an Estuary Polluted by Acid Mine Drainage: The Role of Particulate Matter," Environmental Pollution, Vol. 121, No. 2, 2003, pp. 283-292. doi:10.1016/S0269-7491(02)00216-6

[3] A. Akcil and S. Koldas, "Acid Mine Drainage (AMD): Causes, Treatment and Cases Studies," Journal of Cleaner Production, Vol. 14, No. 12-13, 2006, pp. 11391145. doi:10.1016/j.jclepro.2004.09.006

[4] O. Y. Bittar, "Evaluation of the Recovery of Degraded sites by Mining in the Metropolitan Region of São Paulo," Ph.D. Thesis, Escola Politécnica da Universidade de São Paulo, São Paulo, in Portuguese, 1997.

[5] R. Nascentes, L. P. Ernani, P. S. Silva and I. Azevedo, 
"Heavy Metals Removal with the Use of Coal," REGEO, in Portuguese, 2007.

[6] C. Chen and I. Chiou, "Remediation of Heavy MetalContaminated Farm Soil Using Turnover and Attenuation Method Guided with a Sustainable Management Framework," Environmental Engineering Science, Vol. 25, No. 1, 2008. doi:10.1089/ees.2006.0183

[7] A. Knop, "Study the Behavior of Liners Attacked by Sulfuric Acid," Ph.D. Thesis, Universidade Federal do Rio Grande do Sul, Porto Alegre, in Portuguese, 2007.

[8] A. Lestan, L. Chun-Ling and L. Xiang-Dong, "The Use of Chelating Agents in the Remediation of Metal-Contaminated Soils: A Review," Environmental Pollution, Vol. 153, No. 1, 2008, pp. 3-13. doi:10.1016/i.envpol.2007.11.015

[9] A. K. Das, A. Roy, M. Koschorreck, S. M. Mandal, K. Wendt-Pootthoff and J. Bhattacharya, "Occurrence and Role of Algae and Fungi in Acid Mine Drainage Environment with Special Reference to Metals and Sulfate ImmobilizaTion," Water Research, Vol. 43, No. 4, 2009, pp. 883-894. doi:10.1016/j.watres.2008.11.046

[10] C. A. Maccauley, A. D. O'Sullivan, M. W. Milke, P. A. Weber and D. A. Trumm, "Sulfate and Metal Removal in Bioreactors Treating Acid Mine Drainage Dominated with Iron and Aluminum," Water research, Vol. 43, No. 4, 2009, pp. 961-970. doi:10.1016/j.watres.2008.11.029

[11] S. M. Equeenuddin, S. Tripathy, P. K. Sahoo and M. K. Panigrahi, "Hydrogeochemical Characteristics of Acid Mine Drainage and Water Pollutionat Makum Coalfield, India," Jounal of Geochemical Exploration, 2010, pp. 8.

[12] A. K. Krishna and P K. Govil, "Assessment of Heavy Metal Contamination in Soils around Manali Industrial Area, Chennai, Southern India," Environment Geology, Vol. 54, No. 7, 2008, pp. 1465-1472. doi:10.1007/s00254-007-0927-z

[13] L. Diels, N. Van Der Lelie and L. Bastiaens, "New Develop- ments in Treatment of Heavy Metal Contaminated Soils," Environmental Science \& Bio/Technology, Vol. 1, 2002, pp. 75-82.

[14] A. L. Lafuente, C. González, J. R. Quintana, A. Vazquez and A. Romero, "Mobility of Heavy Metals in Poorly Developed Carbonate Soils in the Mediterranean Region," Geoderma, Vol. 145, No. 3-4, 2008, pp. 238-244. doi:10.1016/j.geoderma.2008.03.012

[15] A. M. Sarmiento, M. Olías, J. M. Nieto, C. R. Cánovas and J. Delgado, "Natural Attenuation Processes in Two Water Reservoirs Receiving Acid Mine Drainage," Science of Total Environment, Vol. 407, No. 6, 2009, pp. 2051- 2062. doi:10.1016/j.scitotenv.2008.11.011

[16] R. N. Yong, A. M. O. Mohamed and B. P. Warkentin, "Principles of Contaminant Transport in Soils," Elsevier, Amsterdam, 1992, pp. 327.

[17] C. D. Shackelford, "Contaminant Transport, Geotechnical Pratictice for Waste Disposal," Chapman \& Hall, London, 1993, pp. 33-65. doi:10.1007/978-1-4615-3070-1 3
[18] C. D. Shackelford, "Cumulative Mass Approach For Column Test," Journal of Geotechnical Enginnering, Vol. 121, No. 10, 1995, pp. 696-703. doi:10.1061/(ASCE)0733-9410(1995)121:10(696)

[19] R. N. Young, W. Z. W. Yaacobl, W. S. P. Bentley, C. Harris and B. K. Tan, "Partitioning of Heavy Metals on Soil Samples from Column Tests. Engineering Geology," Elsevier, Vol. 60, 2001, pp. 307-322.

[20] P. O. S. Costa, "Laboratory Evaluation, of theContaminants Transport in Soil of Landfill Sauipe/Ba," Master's Thesis, Departamento of Civil Engineering, Pontifícia Universidade Católica do Rio de Janeiro, Rio de Janeiro, in Portuguese, 2002.

[21] J. Krahn, "Transport Modeling with CTRAN/W: An Engineering Methodology," GEOSLOPE International, Calgary, 2004.

[22] C. Ochola and H. Moo-Young, "Evaluation of Metal Attenuation through Paper Clay Utilized for Containment of Contaminated Groundwater," Journal of Environmental Engineering, Vol. 130, No. 8, 2004, pp. 873-880. doi:10.1061/(ASCE)0733-9372(2004)130:8(873)

[23] M. P. H. Moncada "Laboratory Study of Collapse Characteristics and Solute Transport Associated with the Infiltration of Caustic Liquor in a Laterite Soil," Master's Thesis, Departamento of Civil Engineering, Pontifícia Universidade Católica do Rio de Janeiro, Rio de Janeiro, in Portuguese, 2004.

[24] H. D. Sharma and K. R. Reddy, "Geoenvironmental Engineering: Site Remediation, Waste Containment, and Emerging Waste Management Technologies," John Wiley \& Sons, New Jersey, 2004, p. 992.

[25] I. C. D. Azevedo, R. C. Nascentes, T. A. Matos and F. R. Azevedo, "Transport Parameters Determination of Heavy Metals in an Oxisol Compacted," Revista de Engenharia Agrícola e Ambiental, in Portuguese, Vol. 9, No. 4, 2005, pp. 623-630.

[26] E. Azambuja, D. B. Cancelier and A. S Nanni, "Soil Contamination by LNAPL: Diagnosis and Remediation Discussion," in Portuguese, GEOSUL 2000, Accessed in 18 June 2006.

http://www.azambuja.com.br/acervo/geosul2000.pdf

[27] A. W. C. Delgado, "Transport Mechanisms of Heavy Metals," National Environmental Congress 2, Mini Course, Salvador, in Portuguese, 2002.

[28] A. V. Streck, "Soils from Rio Grande do Sul," EMATER, Porto Alegre, in Portuguese, 2002.

[29] American Society for Testing and Materials (ASTM), "Standard Classification of Soils for Engineering Purposes: D2487," Philadelphia, 1993, pp. 11.

[30] J. K. Mitchell and K. Soga "Fundamentals of Soil Behavior," 3rd Edition, John Wiley \& Sons Inc, New York, 2005

[31] A. J. Meurer, "Fundamentals of Soils Chemistry," 3rd Editon, Evangraf, Porto Alegre, in Portuguese, 2006, pp. 73-99.

[32] Companhia De Tecnologia Em Saneamento Ambiental 
(CETESB), in Portuguese, Available in 2005, Accessed in June 282006.

http://www.cetesb.sp.gov.br/Solo/relatorios/tabela_valore s_2005.pdf

[33] A. Ogata and R. B. Banks, "A Solution of the Differential Equation of Longitudinal Dispersion in Porous Media," US Geological Survey, Professional Paper, No. 411-A, 1961.

[34] L. N. Reddi and H. I. Inyang, "Geoenvironmental Enginnering: Principles and Applications," Marcel Dekker, New York, 2000

[35] D. E. Daniel, "Geotechnical Practice for Waste Disposal," Chapman \& Hall, London, 1993, pp. 33-65. doi:10.1007/978-1-4615-3070-1

[36] F. A. Vega, "Competitive Sorption and Desorption of Heavy Metals in Mine Soils: Influence of Mine Soil Characteristics," Journal of Colloid and Interface Science, Vol. 298, No. 2, 2006, pp. 582-592. doi:10.1016/j.jcis.2006.01.012

[37] A. T. Matos, M. P. F. Fontes, L. M. Costa and M. A. Martinez, "Mobility of Heavy Metals as Related to Soil Chemical and Mineralogical Characteristics of Brazilian Soils," Environmental Pollution, Vol. 111, No. 3, 2001, pp. 429-435. doi:10.1016/S0269-7491(00)00088-9

[38] M. R. Soares, "Distribution Coefficient (Kd) of Heavy Metals in Soils of São Paulo," Ph.D. Thesis, Escola Superior de Agricultura Luiz de Queiroz, Universidade de São Paulo, Piracicaba, in Portuguese, 2004, p. 202.

[39] L. C. Lange, "Study of Contaminant Transport in Porous Media Applied to Landfill Disposal of Municipal Solid Waste, Alternatives to Solid Waste Disposal for Small Urban Communities: A Collection of Technical Papers," in Portuguese, 2002, Accessed: 22 December 2009. http://www.finep.gov.br/prosab/livros/livrocompletofinal. pdf 